\title{
The congress and convention tourism as a factor of competitiveness at the micro level in the hotel sector of Mérida Yucatán
}

\section{El turismo de congresos y convenciones como factor de competitividad a nivel micro en el sector hotelero de Mérida Yucatán}

GÓMEZ-GALAZ, Karla Gabriela†**, NEGRÓN-NOH, José Jesús Hernán and CABALLERO-KOH, Bertha Loraire

Universidad Tecnológica Metropolitana

ID $1^{\text {st }}$ Author: Karla Gabriela, Gómez-Galaz / ORC ID: 0000-0002-0640-0756, Researcher ID Thomson: Q-9852-2018, CVU CONACYTID: 942603

ID $1^{\text {st }}$ Coauthor: José Jesús Hernán, Negrón-Hoh / ORC ID: 0000-0002-9216-6061, Researcher ID Thomson: Q-98252018, CVU CONACYT ID: 431661

ID $2^{\text {nd }}$ Coauthor: Bertha Loraire, Caballero-Koh / ORC ID: 0000-0002-7238-0933, Researcher ID Thomson: Q-9880-2018, CVU CONACYT ID: 257165

DOI: $10.35429 / J I E C .2019 .4 .3 .8 .18$

Received March 07, 2019; Accepted June 15, 2019

\begin{abstract}
This article shows the results of an investigation based on the analysis of the systematic competitiveness in the congresses and the impact that it represents in the hotel sector of the City of Mérida, Yucatán. It was determined to use the type of exploratory research, with the qualitative and quantitative research approach, the first, because the study will collect historical and recent data related to congress tourism in the city of Mérida.With the results obtained, the impact caused by the congresses within the hotel sector of the city of Mérida, Yucatán is known, identifying the degree of relationship between the authorities that regulate the process of providing accommodation services and that of the people traveling to the city for activities related to congresses. All of this, in order to list the benefits and opportunities that congress tourism brings to the three, four and five star hotel sector in the city of Mérida.
\end{abstract}

Turismo, Competitividad Sistémica, Congresos, Sector hotelero

\begin{abstract}
Resumen
Este artículo muestra los resultados de una investigación basada en el análisis de la competitividad sistemática en los congresos y el impacto que representa en el sector hotelero de la ciudad de Mérida, Yucatán. Se determinó utilizar el tipo de investigación exploratoria, con el enfoque de investigación cualitativa y cuantitativa, el primero, porque el estudio recopilará datos históricos y recientes relacionados con el turismo de congresos en la ciudad de Mérida. Con los resultados obtenidos, el impacto causado por Se conocen los congresos dentro del sector hotelero de la ciudad de Mérida, Yucatán, que identifican el grado de relación entre las autoridades que regulan el proceso de prestación de servicios de alojamiento y el de las personas que viajan a la ciudad para actividades relacionadas con los congresos. Todo esto, con el fin de enumerar los beneficios y oportunidades que el turismo de congresos aporta al sector hotelero de tres, cuatro y cinco estrellas en la ciudad de Mérida.
\end{abstract}

Turismo, Competitividad Sistémica, Congresos, Sector hotelero

Citation: GÓMEZ-GALAZ, Karla Gabriela, NEGRÓN-NOH, José Jesús Hernán and CABALLERO-KOH, Bertha Loraire. The congress and convention tourism as a factor of competitiveness at the micro level in the hotel sector of Mérida Yucatán. Journal- International Economy. 2019. 3-4: 8-18

\footnotetext{
* Correspondence to Author (email: karla.gomez@utmetropolitana.edu.mx)

$\dagger$ Researcher contributing first Author.
} 


\section{Introduction}

Systemic competitiveness supports a theoretical approach in which there must be social integration at different levels and requires a change in the financial, political and technological systems, but it also considers a transformation at the social level. In view of this, many developing, and even underdeveloped countries have the task of overcoming social fragmentation and improving the learning capacity of all their sectors.

The formation of social structures means improving the manufacture of structures at the economic level, since one is complementary to the other, which allows to raise the capacity of its participants, articulating interests and satisfying all their technological, financial, cultural, organizational, environmental requirements, among others.

Systemic competitiveness is distinguished by working with four levels of analysis; micro, meso, macro and meta and researching the interrelationship between them. For Esser, Hilebrand, Messner and MeyerStamer (1996) systemic competitiveness is distinguished by its recognition:

Successful industrial development is not achieved merely through a production function at the micro level, or stable macroeconomic conditions at the macro level, but also through specific measures by government and private development organizations aimed at strengthening the competitiveness of enterprises (meso level). Furthermore, the ability to link meso and macro policies is a function of a set of political and economic structures and a set of sociocultural factors and basic organizational patterns (target level).

On the basis of this framework, it is essential to formulate actions to encourage the creation of factors that will enable to achieve systemic competitiveness in countries and regions, as well as in business sectors, in such a way that these become an active and dynamic component for obtaining competitive advantages. The growth of a sector such as congress and convention tourism, as well as the state of Yucatán, as a national and international tourist destination, and also an entity with constant growth due to public and private investment oriented to all sectors.
It is important to analyze the current conditions that promote the development of systemic competitiveness, both in the tourist instance, as well as in the place where it is developed, that is, the city of Mérida, and of course in the sector of immediate impact, such as the hotel industry.

It was determined to use the type of research of exploratory scope, with the focus of qualitative and quantitative research, that is, the study collects historical and recent data, related to congress tourism in the city of Mérida, Yucatán. The aim is to find out whether congress and convention tourism has an impact on competitiveness at the micro level, the advantages it brings and the degree of interaction between the hotel sector and congress tourism in the city of Mérida, Yucatán.

\section{General objective}

To describe congress and convention tourism as a competitive factor at the micro level in the hotel sector of the city of Mérida, Yucatán.

\section{Hypothesis}

Congress and convention tourism has an impact on competitiveness at the micro level in the hotel sector of the city of Mérida, Yucatán.

\section{Conceptual Framework}

Competitiveness has been considered as one of the factors that strongly influence the economic development of nations, and that lies in the capacity to produce, in a consistent and profitable manner, goods and services that meet the requirements of the markets in terms of quality and price, European Commission (2003). Porter (2008), mentions that competitiveness consists in the production of goods and services of quality and lower price than domestic and international competitors, manifesting itself in increasing benefits for the inhabitants of a nation by maintaining and increasing real income. Similarly, competitiveness can be identified as the ability of a country, a sector or a company to participate in foreign markets (Feenstra, 1989). On the other hand, the concept of competitiveness is the level of production of goods and services that a certain geographical area has through the sustainable use of its resources and the surrounding environmental conditions. 
However, with the passage of time, competitiveness and all its elements have undergone a change due to globalization, since it has developed to the point of radically modifying the competitive environment in which companies operate. The requirements posed by the competition at this time were much greater and more complex than in previous stages.

In this new environment, developing countries face the challenge of generating dynamic competitive advantages, or otherwise being relegated to stagnation and impoverishment. In view of this, the terms of spurious competitiveness, based on low prices of resources (labor, inputs, etc.), have been considered against genuine competitiveness, defined by Fajnzylber (1998), as the process by which a firm generates value added through increases in productivity, and that growth in value added is sustained, that is, it is maintained in the medium and long term.

Within this perspective arises the idea of Müller (1995), which he qualified as sociocultural, because it proposes an explicit relation between efficiency, productivity, competitiveness and improvement of the standard of living of the citizens, which originated the notion of systemic competitiveness.

The systemic competitiveness model, defined by authors such as Messner and MeyerStamer (1994), establishes that "the level of generic competitiveness of a given economy or territory is the result of the organizational and institutional effort of society and of the economic, social and institutional agents that interact in that territory."

Esser, Hillebarnd, Messner and MeyerStamer (1996), on the other hand, identify the concept of systemic competitiveness as that which seeks to respond to the lack of an effective business environment that allows companies to build lasting competitiveness in an increasingly difficult business environment and with the participation of multiple actors. In this way, competitiveness is the product of the complex and dynamic interaction between four economic and social levels of a national system: the micro, meso, macro and meta levels. In this sense, competitiveness is systemic, Benavides, Muñoz and Parada (2004).
For Esser, et al (1994), they mention that the levels of systemic competitiveness are:

Meta level: capacity of the state to lead the economy and the organization that mobilizes social creativity.

Macro Level: covers the macroeconomic conditions necessary for the development of activity supported by fiscal, monetary and budgetary policy reforms.

Meso level: this is the level at which competitive advantages are generated regarding the formation of business clusters, exports, financing and ecological policy.

Micro level: At this level, companies strive to have a competent and innovative administration and a qualified labor force, and they also seek to promote collaboration with suppliers, producers and clients.

Considering the origin of the systemic competitiveness approach and what the authors point out, it can be said that this type of competitiveness is beyond the ideas centralized in economic elements considered by other competitive approaches, since it contemplates other factors besides monetary ones for the development of industries and has a structure that allows evaluating the degree of interrelation of the different participants in the field of study through these four levels. Likewise, it should be noted that the term competitiveness can function in the country as a key element for the development of the regions.

In Mexico, the issue of development has become an important part of government policies and one of the primary objectives within plans at the national and state levels. Thus, development can only be achieved by increasing the competitiveness of all sectors of our nation. To understand the perspective that development can only be achieved through increasing the competitiveness of all sectors of the country, the National Development Plan (2013-2018), mentions the importance of accelerating economic growth to build a prosperous Mexico. It places the development of infrastructure as the key to increasing the competitiveness of the entire nation. 
On the other hand, the State Development Plan of Yucatán (2012-2018), proposes in the competitive axis an increase competitiveness of companies and productivity of its workers, which will result in a stimulus in domestic consumption by improving the income of the companies themselves, providing workers the possibility to access better living standards. Based on the plans, it can be said that by increasing the levels of competitiveness in each sector, it will be possible to have a territorial competitiveness, which will allow producers, workers and consumers to have positive stimuli that will affect living standards, more functional companies, skilled labor, etc.

Territorial competitiveness, according to Calderón (2008), is a product of an environment in which conditions are created and maintained so that the competitive effort takes place, an environment that cannot be improvised but rather built. This environment is precisely the one that occupies the systemic analysis, it is the interaction between the state, enterprises, intermediate institutions and the organizational capacity of society, the generator of the different competitive advantages that can be created and measured. These interactions can be seen in figure 1. systemic competitiveness model presented by Esser, Hillebarnd, Messner and Meyer-Stamer (1996).

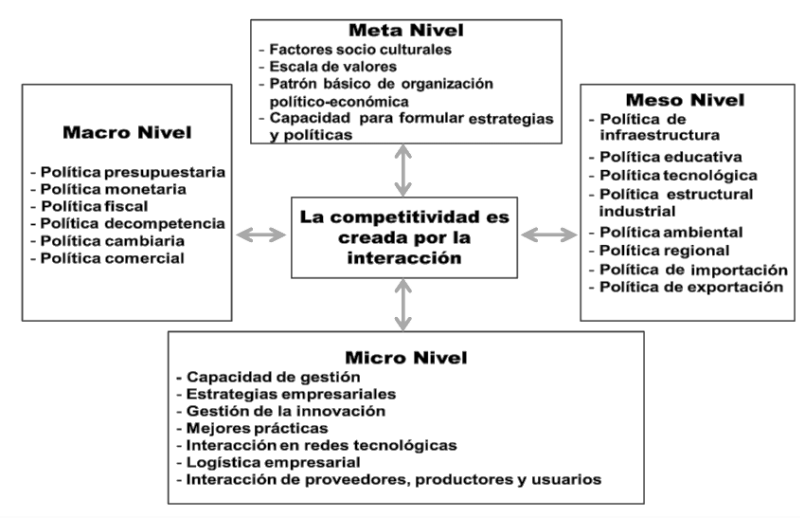

Figure 1 Determinants of systemic competitiveness Source: Esser, Hillebarnd, Messner and Meyer-Stamer (1996)

However, the transition towards territorial competitiveness requires a series of studies and evaluations in each of the areas that make up the national territory. The state of Yucatán, as one of the many regions that make up Mexico, is on the way to integrating knowledge economy.
According to Dahlman and Andersson (2000), a knowledge-based economy is one where knowledge is created, acquired, transmitted and used more effectively by companies, organizations, individuals and communities for greater economic and social development.

For this reason, it is necessary to move away from traditional and knowledge-intensive industries, promoting innovation, technological development and the training of knowledge workers as new competitive advantages, which will give way to the generation of productive jobs and remunerative wages. This means analyzing the strengths of the Yucatán territory; therefore, Lamb, Hair and McDaniel (2010) mention that strengths are all those internal and positive elements that differentiate the program or project from others of the same kind.

To take advantage of them in a timely manner, it implies identifying the determining factors that influence the competitive development of the sectors identified as strengths, and there is no better way to carry out this analysis than with the approach proposed by systemic competitiveness, and even more so when the number of studies under the use of the vision proposed by such approach is nil.

On the other hand, the Tourist Guide of Yucatán (2014), states that Yucatán offers natural attractions, archaeology, history, culture, traditions, legends, and the heritage of a colonial and indigenous past that is reflected in the delicious Yucatán cuisine and in the hands of its artisans and artists. This translates to the Yucatán territory as a tourist destination with great potential, placing tourism as an unquestionable strength for the state.

The tourist destination is the space where the tourist spends at least one night which includes the consumption of products such as basic and supplementary services, World Tourism Organization (2002).

Mérida has several related elements, from a modern hotel and medical service infrastructure, accessibility through modern and safe roads, airports with national and international flights and a high-altitude port in Puerto Progreso. In addition, it is surrounded by many colonial and archaeological tourist attractions. 
All this richness makes the city of Mérida susceptible to transform it even more, in a territory that generates complete tourist products that can enrich even more the tourist offer, combined with the one available at this moment. According to the Tourism Competitiveness Agenda of Mérida (2013), the city has ample potential resources according to the tourism segments of the territory. Taking as a base those tourism segments with potential present in the city of Mérida, Yucatán we find business and convention tourism as an expanding activity, which translates into an opportune area of analysis under the systemic competitiveness approach.

Organizations such as the Council for the Promotion of Tourism in Mexico (CPTM) undoubtedly support the sale of the "Country Destination" abroad, the Ministry of Finance with the tax incentive of "zero" rate of Value Added Tax for conferences and conventions from abroad and the hand of the Office of Conventions and Visitors (OC) of each of the destinations developed and developing, are undoubtedly the anchor to enhance Business Tourism, according to the magazine Líder Empresarial (2007).

This type of tourism has had a strong impact on the state, since the evolution of the organization of congresses has been remarkable, even more so in recent years. The first records we have date from 2003, when Centro Siglo XXI was 6 years old and the promotion as a congress destination was incipient. At that time, 63 congresses or conventions were held in the State, with the participation of 26,220 national or foreign visitors. More than a decade later, in 2015, the growth has been exponential. In the last year, 228 meetings were organized, and 62,234 participants were registered. This is not only a numerical trend, but also a positioning as a destination. Mérida went from 7th place in 2013 to 4th among the most attractive Mexican cities with the best conditions to organize congresses, according to the International Congress and Convention Association (ICCA) ranking of Cities 2015, in line with Meetings Industry ( 2016).

All of this results in the need to strengthen the city's infrastructure and services, in order to have greater participation in congress and convention tourism.
Therefore, we mention the conditions for the further development of meetings tourism: air connectivity, number and quality of hotel rooms and the new International Congress Center. In terms of flights, Mérida now connects with the main cities of passenger distribution in the world and Mexico. In North America, Dallas, Houston, Miami and Toronto concentrate the routes of all the United States and Canada, so that a tourist from these countries, or even in other continents, can reach Mérida with only one stopover, according to the Meetings Industry (2016).

The strengthening of the infrastructure for congress and convention tourism was achieved through the creation of a new convention center, with the linkage of first world international capitals, improvement of the public environment and so on. The participation of a private sector that has a close relationship with this tourism segment, the hotel industry, can be observed.

According to Genise (2010), tourism and the hotel industry are two industries that go hand in hand; without tourism there would be no need for hotel establishments, and without the existence of hotels, a key element in the equipment of the tourism system would be missing. Therefore, the success of tourism has gone hand in hand with the development of the hotel industry, the entrepreneurs of which have invested resources to improve the quality of infrastructure and services offered to visitors in various destinations in Mexico.

Thus, tourism can be defined as that activity that involves the visit and displacement of people from the country or foreigners who make use of the goods and services of the place they visit. According to Rodríguez (2011), event tourism includes congresses, conventions, fairs, exhibitions, incentive travel, festivals. It is a modality of business tourism, which essentially mobilizes opinion leaders in different branches of knowledge, science, technology, finance or trade.

It follows that business tourism is all that involves the arrival of visitors to a place for activities such as congresses and conventions. 
Since Mérida is a complete tourist destination that reflects a diversity of attractions that allow the organizer of congresses, conventions and incentive trips to choose among many alternatives for their work activities, and to have important complements for their events before, during and after them, the task is to analyze this type of activities within the hotel sector, through systemic competitiveness.

\section{Methodology to be developed}

We determined to use the type of research of exploratory scope, with the approach of qualitative and quantitative investigation. In the study, historical and recent data are gathered, related to the tourism of congresses in the city of Mérida, Yucatán. The study was based on the analysis of various sources on systemic competitiveness and was structured on the basis of that literature and the collection of data through a field study applying a structured questionnaire with closed questions and organized in various aspects of systemic competitiveness, for its measurement the Likert scale was applied. Through this method, the hypothesis was contrasted at the micro level in a descriptive way.

Likewise, the population was delimited by selecting the city of Mérida and specifically the population under study is constituted by the entrepreneurs of the hotel sector of three, four and five stars.

\section{Results}

This section describes the results obtained for the most relevant aspects of the research, describing the information generated for the micro level of the systemic competitiveness of the hotel sector.

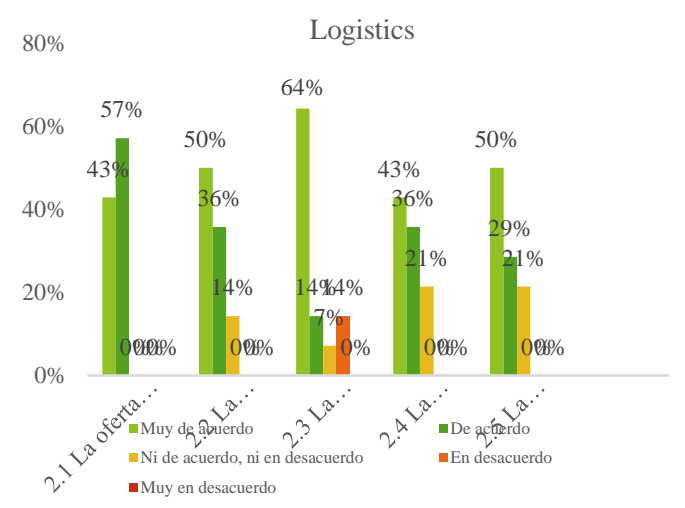

Figure 2 Logistics
The results obtained for the micro level are positive, because it has been identified that in logistics, $93 \%$ of the companies (13 hotels) optimize their resources most of the time to reduce their costs. However, $86 \%$ (12 hotels) of these companies have identified their key processes to minimize costs, therefore, they have a procurement plan to have quality raw materials and inputs, in addition, they have been certified by one or more quality standards and have trained personnel in charge of logistics.

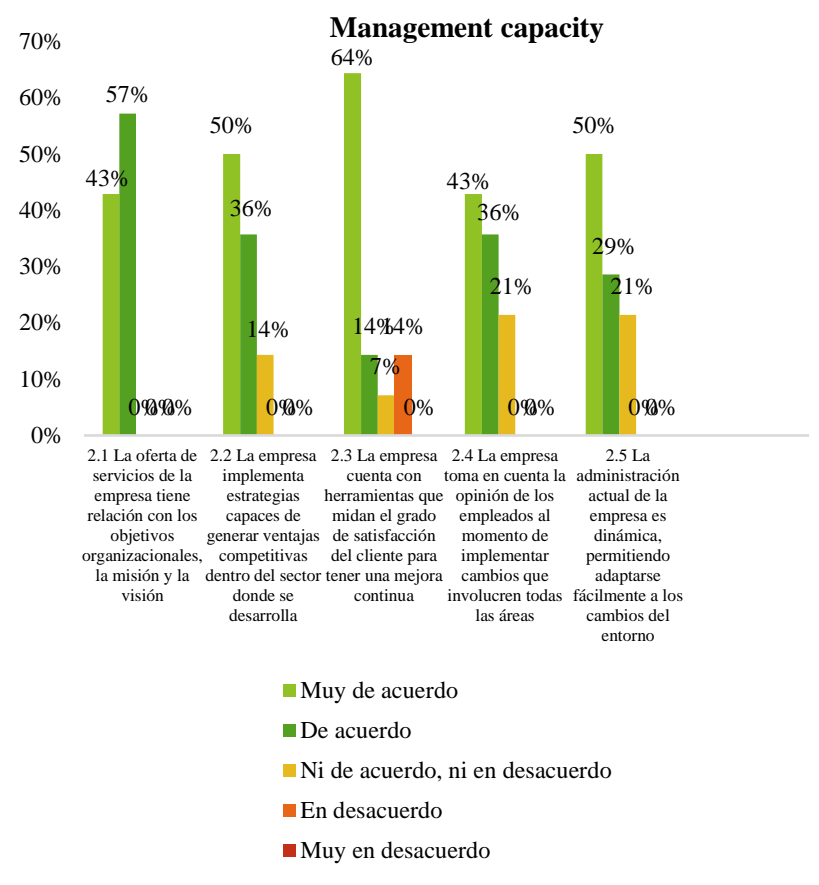

Figure 3 Management capacity

Likewise, in terms of management capacity, it is known that all hotels $(100 \%)$ have the services they offer correctly related to their organizational objectives, mission and vision, where $86 \%$ (12 hotels) of the companies implement strategies capable of generating competitive advantages within the sector in which they are developed and 79\% (11 hotels) of the companies have a dynamic management, allowing them to easily adapt to changes in the environment, this allows them to have tools that measure the degree of customer satisfaction to have a continuous improvement, taking into account the opinion of employees when implementing change. 


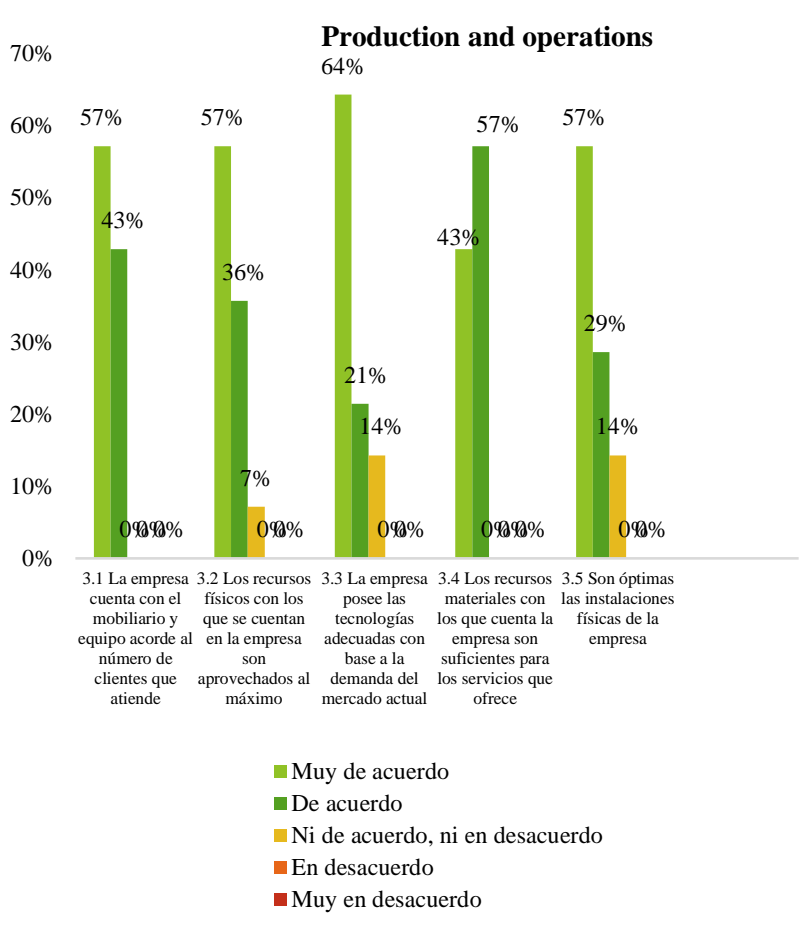

Figure 4 Production and operations

On the other hand, regarding the production and operations indicator, all hotels $(100 \%)$ have the furniture and equipment according to the number of clients they serve, so the material resources they have are sufficient for the services they offer. However, 93\% (13 hotels) of the companies make the most of the physical resources they have, where 86\% (12 hotels) have optimum facilities, which means that they have adequate technologies based on current market demand.

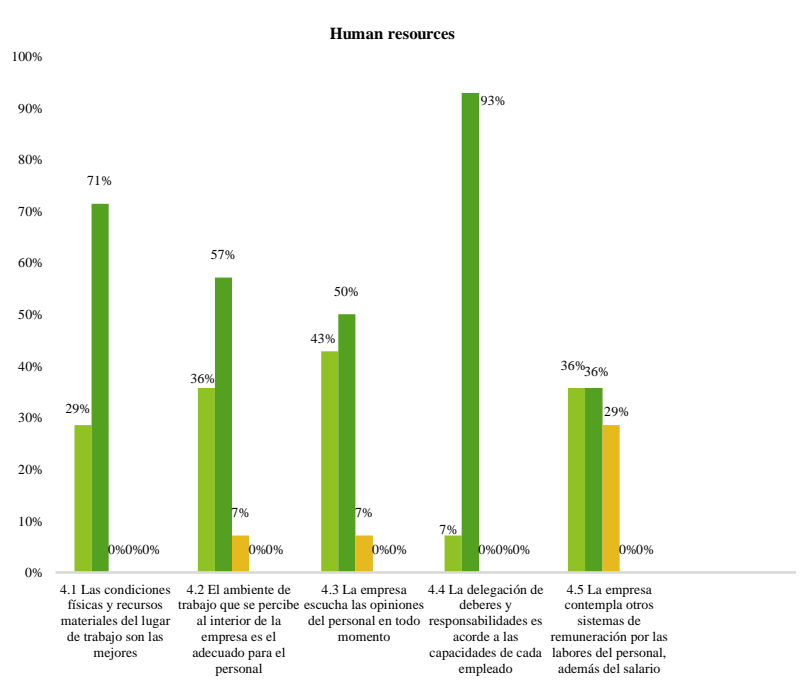

Figure 5 Human resources
Finally, within the human resources indicator at the micro level, it is known that $100 \%$ of the companies (14 hotels) offer the best physical conditions and material resources for the workplace, in which the delegation of duties and responsibilities is in accordance with the capabilities of each employee. It should be noted that $93 \%$ (13 hotels) of these companies perceive an adequate internal work environment for the staff, listening to the opinions of the employees always.

This means that for the micro level, the three, four and five star hotel companies have adequate logistics that allow them to correctly articulate not only the offer of their services in a timely manner, but also the acquisition of raw materials and supplies to carry out all their processes as established.

\section{Conclusions}

Out of a total of 14 hotels surveyed, $43 \%$ (6 hotels) responded that private companies such as DMC's interact with them to offer accommodation services to congress and conversion attendees, another 43\% (6 hotels) mentioned that no other company interacts with them, $7 \%$ (1 hotel) commented that the city's airport and another $7 \%$ (1 hotel) that hotel chains promote accommodation services to tourists for congresses and conventions.

Starting from this premise, the degree of influence of the systemic competitiveness will be greater and better, this does not mean that currently it is not so, the results obtained are good, compared to companies of other tours, but ultimately it is an area of opportunity in which it can be improved to obtain better results. Therefore, the points made by Carrizo and Vieira (2009) are reaffirmed, as regards the particularities that comprise congress and convention tourism, which goes beyond an activity with economic spillover, which articulates and puts in tune the work of different entities at all levels for a financial, social, political, urban-environmental, technological and, of course, tourist benefit.

Event tourism has a very specific feature: the interdependence between the various agents involved, the extent of the event phenomenon and its inter, multi and multidisciplinary nature, which requires knowledge of the economic, social, cultural and environmental reality within a systemic vision and of opportunities.

GÓMEZ-GALAZ, Karla Gabriela, NEGRÓN-NOH, José Jesús Hernán and CABALLERO-KOH, Bertha Loraire. The congress and convention tourism as a factor of competitiveness at the micro level in the hotel sector of Mérida Yucatán. Journal- International Economy. 2019 
It can be said that congresses and conventions, as well as participants who travel to places where these activities take place, have a positive impact on society. Therefore, it is important an impeccable logistics for the organization of congresses and conventions, as well as to have the necessary furniture and equipment, and of course, to reserve the means of transportation for the key participants, this translates into activating the economy of the DMC'S, travel agencies and even banquet companies, being the latter, mostly families, giving way to the benefit of the socioeconomic level that ranges from medium-low, to mediumhigh.

Within this same socioeconomic sector, young people and adults are affected by the creation of temporary and permanent sources of employment, since when the congresses and conventions are held, two major needs that seek to be satisfied by their participants are food and lodging, which are directly reflected in the restaurant and hotel sectors, the latter of which benefits the upper class, considering that most lodging companies are part of prestigious hotel chains. Not to mention that having a new market in sight, that of congress tourists, means for hotel and restaurant companies to increase the acquisition of raw materials, such as perishable and non-perishable products, which would benefit other companies.

On the other hand, throughout the development of the project, we obtained data which was subsequently analyzed. The process to find this was not easy, as information was increasingly scarce as the study was being delimited and, of course, the participation of the subjects of study, especially hotel companies, was not so easily accessible.

During the implementation of this study new questions arise, such as: How can the performance of the instances present in the levels of systemic competitiveness within the hotel sector of Mérida be improved? how can the work of hotel companies be perfected through the systemic approach of competitiveness? since without a doubt, the development of the research work, allowed, from now on, to advance with future investigations within the area of study.
The results of the data obtained by primary and secondary sources confirm what has been revealed by magazines and entities, that congress and convention tourism in the city of Mérida has gained importance, adding the efforts of the public sector with the creation of the International Congress Center of Yucatán and the actions of the private sector through the construction of sixteen hotels with an investment of $\$ 1,500$ million pesos, it is expected that the indexes for congresses and conventions will increase.

Therefore, it is relevant not to lose sight of congresses and conventions, because they are the origin of where tourism activity is derived, since it represents benefits for a significant number of families, family businesses and MSMEs, job opportunities for young people and adults, improvements in services and public works, and of course, the economy of the city and the state, fixing the eyes of Mexico and the world in Yucatán. This shows that the business development of a country is indeed related to the Micro level, since they are in charge of building the lasting competitiveness of the environment, as well as the maximum development of the entity.

\section{References}

Benavides, S., Muñoz, J., \& Parada, A. (2004). El enfoque de competitividad sistémica como estrategiapara el mejoramiento del entorno empresarial. Economía Y Sociedad, p. 119-137. Calderón, F. (2008). Las Políticas Públicas en la encrucijada: políticas sociales y competitividad sistémica. Retrieved from http://www.eumed.net/libros/2008b/391/

Dahlman, C \& Anderson, T. (2000). Corea y la economía basada en el conocimiento: haciendo la transición. Washington, United States Of America: Banco Mundial y OCDE.

Esser, K., Hilebrand, W., Messner, D. \& MeyerStamer, J. (1994, noviembre). Competitividad Sistémica. Harvard Bussines Review, edición (November-December).

Esser, K., Hilebrand, W., Messner, D. \& MeyerStamer, J. (1996, August). Competitividad sistémica: Nuevo desafío para las empresas y la política. Revista de la CEPAL. Número (59). Retrieved from http://repositorio.cepal.org/handle/11362/12025 
European Commission. (2003). European Innovation Scoreboard. Recuperado de http://ec.europa.eu/growth/industry/innovation/f acts-figures/scoreboards_es

Fajnzylber, F. (1998, December). Competitividad internacional: evolución $y$ lecciones. Revista de la CEPAL. número (36). Retrieved from http://repositorio.cepal.org/handle/11362/11714

Feenstra, R. (1989). Trade policies for international competitiveness. Chicago, United States Of America: The University of Chicago Press.

Genise, C. (2010). Hotelería tradicional versus nuevas modalidades de alojamiento. Hoteles boutique y hoteles de estrellas. (Bachelor's thesis). Universidad de Palermo, Buenos Aires, Argentina.

Gobierno de la Republica. (2013). Plan Nacional 2013-2018 de Desarrollo. Recuperado de http://pnd.gob.mx/

Gobierno del Estado de Yucatán. (2012). Plan Estatal 2012-2018 de Desarrollo Yucatán. Retrieved from http://www.yucatan.gob.mx/gobierno/ped.php Industria de Reuniones. (2016). Yucatán compite por el mercado de congresos y convenciones. Retrieved from https://industriadereuniones.com/yucatancompite-por-el-mercado-de-congresos-yconvenciones/

Lamb, C., Hair, J., \& McDaniel, C. (2010). Marketing. Boston, United States Of America: International Thomson Editores.

Messner, D. \& Meyer-Stamer, J. (1994). Competitividad sistémica. Pautas de gobierno y de desarrollo. Revista Nueva Sociedad (número 133), p. $72-87$.

Müller, G. (1995, agosto). El calidoscopio de la competitividad. Revista de la CEPAL número (56), 137-148. Retrieved from http://repositorio.cepal.org/handle/11362/37989

Organización Mundial del Turismo. (2002). Número monográfico dedicado a la investigación sobre el destino turístico y su gestión. Themis Publication. Destination Management. Número (5), p. 10.
Porter, M. (2008, enero). Las cinco fuerzas competitivas que le dan forma a la estrategia. Harvard Bussines Review América Latina volumen (January). Retrieved from https://utecno.files.wordpress.com/2014/05/las_ 5_fuerzas_competitivas-_michael_porterlibre.pdf

Revista Líder Empresarial. (2007). Turismo de negocios, una nueva realidad. Retrieved from http://www.liderempresarial.com

Rodríguez, E. (2011). La industria del turismo de negocios. El negocio del milenio. La Habana, Cuba.

Secretaria de Fomento Turístico (2014). Guía turística de Yucatán. Retrieved from http://occyucatan.com/

Secretaria de Fomento Turístico. (2013). Agenda de Competitividad Turística de Mérida. Retrieved from www.sefotur.yucatan.gob.mx/ 